\title{
Inter-relationship between Citizenship and Globalization: An India Specific Analysis
}

\author{
Cmde SL Deshmukh, NM (Retd) ${ }^{1}$
}

\begin{abstract}
The concept of Citizenship is centuries old and it had stood the test of time. Various countries have tried and adapted different types of citizenships depending on the circumstances. They follow different processes and procedures to grant Citizenship to the applicants who are not covered by the laws governing the natural citizenship. Countries also get affected by the centuries old phenomena of migration (reasons could be many) and migrants too apply for the citizenship. It is important to note that not all applicants succeed in getting the Citizenship, some of them get deported and some suffer with what is termed as 'Statelessness' (as the original country from where they fled, for whatever reasons, also refuses to accept them back). It's a worst state for a human being to exist in. All such relevant aspects related to citizenship have been examined in the paper.
\end{abstract}

Lately many countries have been affected by the population pressures, dwindling natural resources and stressed economies. Efforts to ease such problems by improving the economies and offer better life styles to the citizens have forced liberalisation of trade, leading to free flow of goods, technologies, information and people, transgressing various boundaries and cultures. Despites its advantages and disadvantages, Globalisation has unabatedly propagated. It has been seen that the Globalisation as a phenomenon has globally affected many aspects like political, economic, cultural as well as the concepts of citizenship. Globalisation has also given birth to newer types of citizenships like social and economic, each with its own pros and cons.

India too has been going through various issues like migration across its borders, Rohingya problems, globalisation related migration and its impacts. India has to find cogent measures to address these issues. This paper thus deals with a broad brush canvas related to citizenship and globalisation and attempts to analyse different facets of citizenship, forces propagating globalisation, impact of globalisation on citizenship universally, specific impact on India and ways for dealing with it in India related scenario and some viable suggestion for consideration.

Keywords: Citizenship, Globalisation, Statelessness, UNHRC, Liberalisation, Trade, Migration, Economy, Geography, Technology, Impact, Solutions, India, Rohingya

\footnotetext{
${ }^{1}$ Commodore SL Deshmukh, NM (Retd) served the Indian Navy for over three decades as a specialist in maintenance of fighter aircraft and ASW helicopters. He is currently the Senior Vice President of Sun Group's Aerospace \& Defence vertical.
} 


\section{Inter-relationship between Citizenship and Globalization: An India Specific Analysis}

\section{Introduction}

Citizenship is a boon which bestows many benefits and responsibilities on a person. Many of us take Citizenship and its benefits for granted. But only a few of us make an effort to understand the purport of citizenship, its historical origin, benefits it confers and responsibilities it imposes, effects of statelessness etc. These issues need to be understood by all of us.

Further, the population pressures, dwindling natural resources and stressed economies have forced Globalisation and in turn liberalisation of trade. It has been observed that Globalisation impacts, many aspects like Economies, Finances, Technological prowess and Culture of nations and last but not the least Migration. Globalisation thus indelibly affects countries and their 'Citizenship' aspects.

This article attempts to analyse Concepts of Citizenship, Globalisation Process to understand its linkages, interdependencies, impact on Migration and Citizenship, prevalent scenarios in the world and in India, emerging issues and probable solutions.

\section{Concepts of Citizenship}

'Citizenship' has been defined as:

Relationship between an individual and a state to which the individual owes allegiance and in turn is entitled to its protection. Citizenship implies the status of freedom with accompanying responsibilities. Citizens have certain rights, duties, and responsibilities that are denied or only partially extended to aliens and other noncitizens residing in a country (Britannica, 2020).

\section{Benefits and Responsibilities}

Let us now see some of the benefits related to 'Citizenship'. In general, full political rights, including the right to education, vote and to hold public office, are some important benefits from citizenship. The usual responsibilities of citizenship are allegiance, taxation, and military service. 
Citizenship is the most privileged form of nationality. This broader term denotes various relations between an individual and a state which may or may not confer political rights but certainly offer other privileges, particularly protection abroad. Citizenship is thus a term used, in international law, to denote all persons whom a state is entitled to protect. Nationality also serves to correlate relationship to a state of entities other than individuals. It is important to note that corporations, ships, and aircraft, for example, possess a nationality. Let us now examine various facets of Citizenship.

\section{Citizenship -Historical Perspective}

The fact that citizenship is the most privileged form of nationality has been acknowledged since long. If we peep into history, it would be seen that the concept of citizenship originated in towns and city-states of ancient Greece. Citizenship was used as an instrument by Romans to distinguish the residents of the city of Rome from persons belonging to the territories conquered by them. As the Roman Empire grew, citizenship was granted by the Romans to their allies throughout Italy. It was further extended to the peoples in other Roman provinces, wherein by $212 \mathrm{CE}$ citizenship was extended to all free inhabitants of the empire. It is important to note that the Roman citizenship granted important legal privileges to its citizens.

Sadly, the concept of 'national citizenship' virtually disappeared in Europe during the Middle Ages, replaced as it was by a system of feudal rights and obligations. This disappearance later had disastrous ramifications for human race in countries like Italy and Germany.

The modern concepts of citizenship were understood and evolved in the 18th century, especially during the American and French Revolutions. During those times the term Citizen denoted possession of certain liberties in the face of the coercive powers of hegemonic monarchs.

As far as England was concerned, the term 'Citizen' originally referred to membership of a borough or local municipal corporation, while the word 'subject' emphasized the individual's subordinate position relative to the monarch or state. Interestingly, the word subject is still used in preference to citizen in British common-law usage and nationality legislations, however the two terms are now almost equivalent as the British constitutional monarchy is now a ceremonial one, without political powers over its subjects (Britannica 2020a). This concept is more or less prevalent in many countries now. 


\section{Various Types of Citizenship}

It has been observed that the principal grounds for conferring citizenship (apart from international transactions such as transfer of territory or option) are birth within a certain territory, descent from a citizen parent, marriage to a citizen, and naturalization.

Two main systems are used to determine citizenship rights. First one is as of the time of birth or 'jus soli', whereby citizenship is acquired by birth within the territory of the state, regardless of parental citizenship. Second is; jus sanguinis', whereby a person, wherever born, is a citizen of the state if, at the time of his or her birth, his or her parent is citizen of that country.

The United States and the countries of the British Commonwealth follow the 'jus soli' concept as their basic principle. They also recognize acquisition of nationality by descent, but it is subject it to many strict limitations. Other countries generally adopt the 'jus sanguinis' as their basic principle. They also have provisions for acquisition of citizenship in case of combination of birth and domicile within the country, birth within the country of parents born there, and so on (Britannica, 2020b).

It has been seen that usually citizenship based on circumstances of birth is automatic, but an application/registration may be required. Other types of Citizenships cover:-

a) Citizenship by marriage (jus matrimonii)

b) Naturalization

c) Citizenship by investment or Economic Citizenship.

Some scholarly works have highlighted a new perspective to 'Citizenship'. As per those (Elliott and Turner, 2012 and Turner, Oct10, 2017) the citizenship could be broadly classified in five categories:-

a) National Citizenship typically associated with ethno-nationalism. This became important in nation-building processes from the 19th century onwards.

b) Latin American type national citizenship which was connected with various nationbuilding projects. However, the Latin America experienced an authoritarian and militaristic version of nationalist citizenship, as a historical consequence of Iberian colonisation.

c) Social citizenship was closely connected to civil society institutions rather than to the state or the market. It involved creation of the social rights, in association with 
development of the welfare state and was consequently referred to simply as "welfare citizenship'. This form of citizenship was prevalent in the Scandinavian societies in 20th Century.

d) The fourth type of citizenship relates to identification of the citizen with participation in the work force, emphasising self-reliance and autonomy. This type of citizenship was pre-eminently explored by the political philosopher Judith Shklar, in USA.

e) The fifth type of citizenship relates to Passive Citizenship. In that, consumerism or presupposition of a consumer society, a weak state and the decline of civic institutions become predominant and the passive citizen becomes a consumer of privatised goods and services. With predominance of e-commerce and on line services the passive citizen willingly moves towards passive isolation. The normal facilities for the traditional citizens like the malls, cafés, meeting halls, clubs and the places for religious congregation get replaced by online networks, and the social solidarity is more elastic rather than 'sticky'

But it is important to note that the above forms were never entirely separate and various combinations were always possible, producing hybrid traditions of citizenship; as a result, they could be regarded as the pioneers to the modern day citizenship models (Turner ibid).

As we have seen the Citizenship confers many rights and privileges on the people which allow both - the country and its citizens to progress and prosper. However, sadly even today we have people who have been refused citizenship and it would be important to briefly examine plight of such stateless people.

\section{Statelessness}

For many of us, who are citizens of a country, it would not be easy to imagine effects of 'statelessness'. Without citizenship, a person cannot register to vote in the country in which he lives, cannot apply for a travel documents and cannot register to marry. In some instances, individuals who are stateless and are outside their country of origin or country of former residence are detained for long periods, if those countries refuse to grant them re-entry. Often, even the most basic of rights - the rights to education, medical care, and employment - are denied to individuals who cannot prove the link of nationality with a country. No country in the world is free from the problems that lead to statelessness. UNHRC estimates that millions of people around the world are living without any nationality/citizenship. 
For Redressal of 'Statelessness' UN members have been advised by UNHRC (Achiron, Nov 2005) to formalise as law the Statelessness determination procedures, ensuring fairness and transparency. UNHRC's Handbook on Protection of Stateless Persons provides a comprehensive list of due process rights to be respected, including:

a) Access to an interview and legal aid;

b) Interpretation assistance;

c) Deadlines within which statelessness determinations must be made from the time an application is filed;

d) Right to receive written reasons for a decision; and appeal against first-instance rejection of an application.

It is hoped that with such measures in place issue of Statelessness would get addressed effectively and plight of stateless people would improve. After examining issues related to Citizenship and Statelessness it would be important to study the impact of 'Globalisation' on citizenship.

\section{Globalisation: Facets and Impacts}

\section{Globalisation}

Let us first examine what is Globalization. In simple terms Globalisation denotes the speedup of movements and exchanges (of human beings, goods and services, capital, technologies or cultural practices) all over the world. One of the effects of globalization is that it promotes and increases interactions between different regions and populations around the globe.

WHO (World Health Organisation) has defined the globalisation as "the increased interconnectedness and interdependence of peoples and countries. It is generally understood to include two inter-related elements: the opening of international borders to increasingly fast flows of goods, services, finance, people and ideas; and the changes in institutions and policies at national and international levels that facilitate or promote such flows." (WHO, ND)

Another researcher has defined the process of Globalisation as "In imaging globalization, we might describe the current predicament as one of employing a language inflected with territorialized constructions of space to express the complicated and shifting spatial dynamics of a deterritorialized globe ( Cuddy-Keane, Sep 2003) 


\section{Facets of the Globalisation}

\section{Globalization and the Economy}

The Committee for Development Policy (a subsidiary body of the United Nations), has defined the globalization from economic point of view as (UNHRC Report, ND):

"(...) the increasing interdependence of world economies as a result of the growing scale of cross-border trade of commodities and services, the flow of international capital and the wide and rapid spread of technologies. It reflects the continuing expansion and mutual integration of market frontiers (...) and the rapid growing significance of information in all types of productive activities and marketization which are the two major driving forces for economic globalization."

\section{Globalization in Geography}

From Geographical point of view the globalization has been defined as the set of processes (economic, social, cultural, technological, institutional etc.) that contribute to the relationship between societies and individuals around the world. It is a progressive process by which exchanges and flows between different parts of the world are intensified (Youmatter, Oct 06, 2020).

\section{Different aspects of the Globalization (Concept Map)}

In view of the trade developments and financial exchanges, globalization is often thought as an economic and financial phenomenon. However, Globalisation includes a much wider field than just flow of goods, services or capital. In what can be referred to as the Globalization Concept Map (Ghaderi, Sep 20, 2015), some examples which could be cited to indicate different aspects of the Globalisation are:-

a) Economic globalization: This covers the development of trade systems within transnational actors such as corporations or NGOs;

b) Financial globalization: This is linked with the rise of a global financial system with international financial exchanges and monetary exchanges. Stock markets can be a good example of the financially connected global world as one declining stock market affects other markets negatively as well as the economy as a whole. 
c) Cultural globalization: This refers to the interpenetration of cultures which more often than not results in nations adopting principles, beliefs, and costumes of other nations, losing their unique culture to another unique globalized supra-culture;

d) Political globalization: This is a very peculiar phenomenon in which the development and growing influence of international organizations such as the UN or WHO makes governments to initiate actions at an international level, which have impact at universal levels. There are other bodies operating a global level such as NGOs like Doctors without borders or Oxfam.

e) Sociological globalization: In this form information moves almost in real-time, together with the interconnection and interdependence of events and their consequences. People move all the time too, mixing and integrating different societies;

f) Technological globalization: This phenomenon represents a medium by which millions of people are interconnected by the power of the digital world via platforms such as Facebook, Instagram, Skype or You-tube.

g) Geographic globalization: This relates to transformation in organization and hierarchy of different regions of the world, which is changing dynamically. Moreover, with transportation and flying made so easy and affordable, apart from a few countries having demanding visa conditions, it is possible to travel the world with minimal restrictions.

h) Ecological globalization: This accounts for the idea of considering planet Earth as a single global entity in consonance with Indian Ethos of 'Vasudhaiv Kutumbakam'. For the common good of the world all societies need to protect environment as the weather affects everyone. This is important in view of the fact that the poorest countries that have been polluting the least will suffer the most from climate change (Youmatter, Oct 06 2020a). A figurative representation of concept map of Globalisation (Ghaderi, Sep 20, 2015a) has been placed at Annexure.

Cuddy-Kane (Cuddy-Keane, Sep 2003a) has corroborated above views by the following observation:

Globalization is moving toward increasing complexity and toward increasing simplification, toward grander and more intricate conceptualizations of the whole and 
toward the face of a stranger whose eyes our own are meeting for the first time. There has been a great deal of discussion of the global and the local-of the ways globalization intensifies the local and is experienced through the local, of the ways the local frames the experience of globalization differently for people differently situated in the world. The globalisation may also take people towards a renewed awareness of our personal relations with other spaces and persons.

It can, therefore, be surmised that Globalization impacts various facets related to people and nations. This in turn affects the Citizenship.

\section{Globalization- Advantages and Disadvantages}

Globalization has its own advantages and disadvantages. The benefits of the Globalisation cover many different areas. It has reciprocally developed economies all over the world and increased cultural exchanges. It has also allowed financial exchanges between companies, changing the paradigm of work. Globalisation has made many people citizens of the world. The origin of goods has become secondary and geographic distance does not act a barrier for many services to happen.

\section{Advantages of Globalisation}

\section{Economic Impact through the Engine of Globalization}

The most visible impacts of globalization are seen through their impact on the economic world. Globalization has led not only to a sharp increase in trade and economic exchanges, but also to a multiplication of financial exchanges. Historically, the world economies opened up in 1970s and the development of free trade policies accelerated the globalization phenomenon. Statistically, the world exports increased 33-fold during the period 1950-2010. This significantly accelerated the interactions between different regions of the world.

This acceleration in economic exchanges has led to strong global economic growth. It in turn led to rapid global industrial and technological development. Knowledge became easily sharable and international cooperation among the brightest minds accelerated Globalisationmaking it a positive developmental cycle. According to some analysts, globalization has also contributed to improving global economic conditions, creating much economic wealth- tough unfortunately unequally distributed (Youmatter, Oct 06, 2020b) 


\section{Financial Impact through Globalization}

The Globalisation impacted the world 'finance' too. Since the 1980s, led by neo-liberal policies of USA, the world of finance gradually opened. To cite an example, the US under Ronald Reagan and the UK under Margaret Thatcher introduced the famous '3D Policy' of Disintermediation, Decommissioning, and Deregulation.

This led to simplification of the finance regulations, eliminated mediators and broke down the barriers between the world's financial centers. This financial globalization has contributed to the rise of a global financial market in which contracts and capital exchanges have multiplied.

\section{Cultural Impact through Globalization}

The rapidly growing economic and financial impacts of the globalization led to inevitable cultural globalization. The multiplication of economic and financial exchanges has been followed by an increase in human exchanges such as migration, expatriation or traveling. These human exchanges have contributed to the development of cultural exchanges. Some good examples of cultural globalization refer to the trading of commodities such as coffee or avocados. Coffee is said to have originated in Ethiopia and was initially consumed in the Arabic region. However, due to commercial trades since the 11th century, Coffee has become globally consumed commodity. Similarly, Avocados were mostly grown in the tropical temperatures of Mexico, the Dominican Republic or Peru. But today guacamole or avocado toasts are common in meals all over the world.

Similarly, books, movies, and music are now instantaneously available all around the world thanks to the development of the digital world and the power of the internet. These are perhaps the greatest contributors to the speed at which cultural exchanges and globalization are happening. Other examples of globalization relate to spread of traditions like Black Friday in the US, the Brazilian Carnival or the Indian Holi Festival. They all were originally created following their countries' local traditions and beliefs, but as the world got to know them, they are now common traditions in other countries too (Youmatter, Oct 06, 2020c)

It would be seen that the Globalisation has had an indelible impact of people and its affects their lives in many ways including migration to different parts of a country or other countries. It would thus understandable that Globalisation would have an impact on Citizenship aspects too. 


\section{Negative Effects of Globalization}

Through the analysis done so far we have seen that the Globalization is a complex phenomenon. With GOOD it has considerable negative influences on multiple areas of contemporary societies. Some of the major aspects related to negative impact of the Globalisation have been highlighted in the subsequent paragraphs.

\section{Negative Effects of Globalization on Cultural Aspects}

Apart from all the benefits globalization has had on allowing cultural exchanges it also homogenized the world's cultures. That's why specific cultural characteristics from some countries are disappearing.-from languages to traditions or even specific industries. That's why according to UNESCO, the mix between the benefits of globalization and the protection of local culture's uniqueness requires a careful approach.

\section{Negative Effects of Globalization on Economic Situation}

Despite its benefits, the economic growth driven by globalization has not been done without attracting criticism. The consequences of globalization are far from homogeneous: income inequalities, disproportional wealth and trades that benefit parties differently can be cited as examples. One of the criticisms that some actors (countries, companies, individuals) benefit more from the phenomena of globalization, while others are sometimes perceived as the "losers" of globalization, deserves careful examination. As a matter of fact, a recent report from Oxfam says that $82 \%$ of the world's generated wealth goes to $1 \%$ of the population.

\section{Negative Effects of Globalization on the Environment}

Many critics have also pointed out that globalization has negative effects on the environment. Thus, the massive development of transport that has been the basis of globalization is also responsible for serious environmental problems such as greenhouse gas emissions, global warming or air pollution.

At the same time, global economic growth and industrial productivity are both the driving force and the major consequences of globalization. They also have big environmental consequences as they contribute to the depletion of natural resources, deforestation, destruction of ecosystems and loss of biodiversity. The worldwide distribution of goods is also creating a big garbage problem, especially plastic and e-waste pollution (Youmatter, Oct 06, 2020d and Huwart and Loïc, 2013) 
All the above aspects adversely impact human life. It is now evident that the Globalization affects all sectors of activity to a greater or lesser extent. By accepting large-scale industrial production and the globalized circulation of goods, globalization makes us stand in stark opposition to concepts of resource economisation, energy savings, limitation of greenhouse gases etc.

As a result critics often argue that the Globalisation contributes to accelerating climate change and that it does not respect the principles of ecology. They also point out that big companies (MNCs) generally don't employ locals and prefer to outsource the work to the low wage countries (to have lower costs) or pay taxes in countries with more favourable regulations. This almost negates the criteria of civic welfare approach. Moreover, the ideologies of economic growth and the constant pursuit of productivity that come along with globalization, also make it difficult to design a sustainable economy based on resilience.

Despite above and as a balancing opinion it needs to be accepted that globalization (disadvantages notwithstanding) is needed for the transitioning to a more sustainable world. This is attributable to the fact that only global synergy can really help in true ecological transition. Issues such as global warming indeed require a coordinated response from all global players. We have to concede that the fight against $\mathrm{CO} 2$ emissions, reduction of waste, effective transition to renewable energies, combating ocean/air pollution/ocean acidification are problems that can't be solved without global action (Youmatter, Oct 06 2020e and Huwart and Loïc, 2013 ).

In summary one can say that globalisation comes with its own pros and cons. However, it is evident that despite its disadvantages Globalisation is here to stay and has and will continue to have a lasting impact on the global environment, migration, human populous and aspects related to Citizenship.

\section{Generic Impact of Globalisation on Citizenship}

Global need for economic advancement necessitated reduction of trading barriers coupled with the advancing technologies. That in turn led to an inevitably globalised world and influenced many areas including the concepts and practices of citizenship.

As we now know Citizenship is mostly considered as a combination of rights and obligations that accompanies specifically defined membership of a nation-state. However, the Globalisation resulting in mass flows of information, goods, capital and people has challenged 
the age old established frameworks of citizenship. In addition to the above, citizenship has been transformed in two levels, vertically - between individual citizens and political authorities as well as horizontally - between citizens (Kabeer, Dec 27, 2005) and also at philosophical and a practical levels.

The ongoing process of globalization has irreversibly changed the fundamentals of the global trade, production, sourcing and outsourcing to countries with cheap labour, most notably Asia, as well as the global mobility of virtually anything. As a result the world has become a complex system of interconnectedness and interdependence on both state and individual levels. At the same time, the importance of the nation-states has seemingly decreased. In some cases, some of the largest multi-national corporations (MNCs) have become dominant and even more important than most states (Kivisto and Faist, 2007, p. 102, Soysal, 1994, Vuskane, 2011).

However, despite the increasing Globalisation, the world still remains affected by poverty, religious persecutions, political strife, economic rumblings due to population pressures and dwindling natural resources. All these result in global transition or migration of people from one country to another, for various reasons (Vuskane, 2011a). Let us now examine some major causes for Migration of people.

\section{Why People Migrate?}

Immigration has existed throughout the history of humankind and people have moved from their home places for centuries, for various reasons (Montiglio, n.d) like:-
a) Escape from Conflict Zones
b) Due To Environmental Factors
c) Escape Poverty
d) Attain higher Standard Of Living or better living conditions
e) Personal Needs
f) Higher Education
g) Love
h) Family Influences
i) Better Healthcare
j) Be Closer to Nature and/or Adventurism
k) Political Reasons
1) Missionary work 
The Globalisation has certainly accelerated migration due to reasons mentioned at points c, d, $\mathrm{e}, \mathrm{i}$ and $\mathrm{k}$ above. Above logic and reasoning has also been supported by other scholars too (Nunez..et al, Dec 04, 2014). The pressures such migration creates on economic, political, cultural aspects of countries which in turn undoubtedly affect their Citizenship scenario.

\section{Impacts of interlink between Globalisation and Migration on Citizenship}

It is evident by now that Migration is an intrinsic part of globalization process. It is also a salient political issue that currently dominates local, national, regional and global scenarios. Despite that, the globalization has become a necessary evil, in today's environment, as it helps in improvement in economies with free flow of capital, goods, information and people. However, there are divergent views as to how it affects the patterns and reasons for mobility and in turn Citizenship. Some researchers have argued that globalization leads to more migration and to higher welfare gains and/or costs. It has also been observed that in the field of migration, globalization is better described as asymmetrical, with migrants moving to a small pool of select countries (Czaika \& de Haas, 2014). This does have an impact on Citizenship aspects.

A group of researchers (EPCR, Jul 2016) has opined that the migration issues have now become a global problem. It has specifically highlighted example of European Union and pointed out that:-

a) European migration and refugee crisis has challenged the aspect of citizenship and need for some controls have been felt.

b) The migration has affected the very common understanding of "global governance of migration" and raised questions about the extent to which human mobility can be tamed and made predictable through governance techniques, such as migration management.

Their study, which dealt with different levels (global, regional and bilateral) of migration, has helped in better understanding of multi-layered migration governance and its interactive influence on cooperative efforts between states to deal with migratory movements. It has been observed that though axiomatically control of migration is supposed to be done by states and state administration (e.g. border controls), in reality more actors/agencies are involved.

Analysts have observed that multi-layered migration control involves many different agencies with different interests, capacities (other than states), where in migration governance goes 
beyond the control of migration. It has also been seen that Migration Governance has 'Security Implications' which in turn affects Citizenship.

EPCR researchers (EPCR, ibid) have also examined migration management through the lens of geographies of control. They have pointed out that:

The current ( especially EU) practices in the field of international migration reflect the fact that borders although axiomatic of where control traditionally takes place, are being supplemented by a variety of practices of control, such as selection of (labour) migrants or asylum seekers with credible claims of persecution that take place elsewhere than at the border.

Scholars have also examined the gamut of Governance, Citizenship and Sovereignty. They have analysed the impact of the global governance of migration on traditional political concepts such as, citizenship. It has been pointed out that as a result of globalization it has become necessary to develop new political concepts to express the relationship between persons and political entities in a globalized world. It is important to clearly define the legal and political concepts of citizenship for migrants and refugees on one hand and the relationship between individuals, territory and authority on the other.

While globalization has opened up the avenues for multicultural societies, it is eroding state sovereignty over borders. It has been noticed that in Europe, Globalisation has led to increase in populism, right-wing politics and a return to nationalism as a cultural and political construct. The emerging political construct has affected the understanding of legal and political membership and the fact that globalization impacts nationalism and citizenship has been acknowledged. (EPCR, Jul 2016a).

Another researcher Koser (Koser, Mar 2018) has rightly commented on the subject stating that:

International migration is inextricably linked with globalisation. On one hand, processes of globalisation drive international migration, including through disparities in development, demography and democracy; the global jobs crisis; the segmentation of global labour markets; revolutions in communications and transportation; and transnational social networks. On the other hand, international migration itself generates processes of globalisation, including the global transfer of money and goods; the emergence of global cities; and growing social and cultural diversity. 
In comparison with trade and capital, however, the global movement of migrants remains restricted. This is because international migration strikes at the heart of issues that are paramount to sovereignty, including national identity, economic competitiveness, and security. Hence the paradox that while most industrialised countries require and welcome more migrants to fill labour market gaps and address demographic trends one hand, they nevertheless restrict migration in response to political and populist pressures, on the other.

It is evident from the above that Globalisation and Migration are clearly interlinked and have a serious impact on Citizenship.

\section{Newer Types of Citizenships}

With the advent of Globalisation newer types of Citizenships have emerged:-
a) Social Citizenship
b) Economic Citizenship

\section{Social Citizenship}

Social citizenship has been fundamentally defined as a moral and civic commitment to equality and justice. It is based on the assumption of a "notion of the common good and the commitment to ensure the rights to exercise the concomitant duty of participating in its definition and its fruits" (Navarro, Apr 2005). Another view states that social citizenship includes "the whole range from the right to a modicum of economic welfare and security to the right to share to the full in the social heritage and to live the life of a civilized being according to the standards prevailing in society" (Marshal, 1950).

Social citizenship rights are commonly analysed in economic terms e.g., de-commodifying labour, protection against risks to earning capacity, reducing poverty and redistribution of wealth. But, the core of Social Citizenship still fundamentally remains moral. However, European Union is already experiencing increasing strains in solidarity from the socially excluded and the large number of cross-border migration from all over the world (Handler, September 2002).

\section{Economic Citizenship}

Citizenship by Investment or Economic Citizenship depicts a scheme by which a person becomes a naturalised citizen of another country by investing in that country. Many countries in the world, including India, offer permanent residency status after a significant contribution 
to the economy and proof of residency in that country for a specified number of years. Some other countries like Antigua, St. Kitts and Nevis, Dominica, and Grenada only require a certain sum of money (Radhakrishanan, July 30, 2018). Economic citizenship has its own pros and cons too.

The further analysis on these would be taken up later in particular reference to India.

\section{Indian Scenario}

\section{Issues Related to Migration}

The recent Rohingya crisis in South Asia raised questions regarding the refugee policies in India (Raj, June 06, 2020). Before diving into India specific issues, it would be prudent to understand Asia related issues on the subject.

It's a fact that cross-border movements of population in South Asia have been regarded as a serious issue, as it affected internal security, political stability, jobs and economic stability and international relations. Thus the thrust of several state policies in the region has been to close borders and to clearly define who is a citizen in a particular region. Undoubtedly, this is a very challenging task- both for the citizen as well as for the state $\neg$ because historically, borders were not clearly demarcated or did not exist and people moved freely with little regard for national boundaries or legal notions of citizenship (Kymlicka and Norman, 1994, Raj, June 06,2020a).

India is no exception. India shares porous borders with its neighbours like Bhutan, Bangladesh, Myanmar, Pakistan and Nepal. With globalisation and increase in India's stature- both in economic and political fields- influx of migrants from these countries and there spread in various regions in India has become an issue. This is due to the fact that migrants seem to have changed the demography, employment and economic conditions. Further, impact on political conditions is causing security concerns. This gravity of the issues related to Migration was highlighted by Solicitor General of India (Anand, March 26, 2021) during his submission to the Hon Supreme Court of India, where in he stated that

"India could not be the capital of illegal migrants from across the world. It was not within the 'court's domain' to dictate to the Centre about its foreign relations. The continuance of the illegal immigration of Rohingyas into India and their continued stay in India, apart from being absolutely illegal, is also found to be having serious national security ramifications and poses serious security threats." 


\section{Issues Related to Globalisation}

Another study has examined specific impacts of Globalisation on India. It has been pointed out that Globalization has increased interdependence and has created global competition for India. Globalisation has also enhanced the interdependence of goods-service and capitaltransport. The effects of globalisation have gone beyond global economic trends, affected the regional strategies and circumstances due to international, global and economic causes. It has be seen that options for formulating revised domestic strategy have been limited, indicating a lack of systemic authority in national decision-making (Manhas, June 2020). Let us now examine the impact of globalisation on India:-

\section{Challenges: Social}

a) As in any developing country, job destruction has led to a reduction in workers in industrial sector

b) Communicable diseases have increased.

c) Migration levels have increased,

d) Security environment has been impacted.

e) State's Policy making powers have been impacted.

Challenges-Economic: Manhas (Manhas, 2020a) points out the following challenges:

a) India's trade volumes are dropping

b) FDI flows to India have remained below $0.5 \%$ of GDP as other countries like Vietnam, Bangladesh became more lucrative destinations.

c) Rupee value has eroded.

d) Infusion of state of the art technologies by the foreign companies (to help the Indian industry to grow and profit from the effect of globalization) has led to rising unemployment and poverty.

e) Big multinationals are affecting economic policies.

f) Farming sector has been affected.

All the above effects of Globalisation have impacted the lives of people in India. Indian Government has been trying to balance the development against the negative impacts of Globalisation. India has been traditionally dealing with effects of migration resulting out of 1947 Partition, 1971 War and migration from Nepal/Sri Lanka/Bangladesh/Myanmar. However, increased migration ( both internal and external) attributable to Globalisation and 
some other minor factors has started affecting the demography in various regions like Assam, Jammu \& Kashmir and West Bengal etc. as well as national economy (Roy and Debnath, 2011)

Indian Government is thus weary of according Citizenship to every migrant or refugee coming to India. India is fully cognisant of its obligations under the 1954 convention of UNHRC and trying its best to comply with them. However, such considerations cannot override national interests and national security. India has thus formulated certain policies like National Register of Citizenship (NRC), Citizenship Amendment Act (CAA). However these are facing opposition at both domestic and global levels (Mohanty, Dec 24, 2019). It is thus becoming difficult for India to formulate policies which would ensure development through globalisation and at the same time better the life for its citizens and mitigate its security concerns (Radhakrishnan, July 30, 2018a).

In addition to the above, India has to deal with adversaries like China and Pakistan, impacts of China's Belt and Road Initiative (BRI), China Pakistan Economic Corridor (CPEC) and related debt traps for India's neighbours, impact of Regional Comprehensive Economic Partnership (RCEP) Treaty. India has enough on its platter to deal with both on economic and security fronts, thus caution is advisable while dealing with impacts of both globalisation and migration.

\section{What India needs to do?}

As discussed above we have seen various impacts of Globalisation on Indian Citizenship. India has no option but to deal with those and adapt innovative approach to address the emerging issues.

With irreversible Globalisation in place India may need to progressively move towards Citizenship which would be more suitable for Indian culture and social environment. Let us examine Social Citizenship and Economic Citizenship aspects in the context of India.

\section{Social Citizenship in India}

It has been observed that the social discrimination has been predominant and has been accepted as a fact in the scheme of planned development and finds reflection in positive discrimination policies of India. These policies of positive discrimination were initially limited to education and the provision of public sector jobs to Dalits and Adivasis (Reservations). Certain proportions of seats were also reserved for Dalits and Adivasis in India's national parliament and state legislative assemblies. Later, reservations in jobs and educational institutions were 
extended to Other Backward Classes. Unfortunately, the basic concept for reservations has been distorted and is now being used as political tool to garner the benefits by powerful groups.

Questions which, therefore, emerge are:-

a) Whether the social citizenship concept has been able to address the socio-economic concerns of the economically backward social groups?

b) Whether current policies mitigate longstanding and sometimes discriminatory actions against them?

Available evidence clearly reveals that majority of such social classes still remain underrepresented in better paid and higher status work, and disproportionately concentrated among those drawing lower salaries/wages in both formal and informal sectors (Harries-White, Prakash, Mishra, January 2013). Thus due to prevailing complex diversity issues, social citizenship concept has succeeded only partially and it would not be easy for India to make it a main pillar for Indian Citizenship.

\section{Economic Citizenship: A Way Forward}

The conflicting processes of rapid capitalistic transformation and democratic assertions through fair electoral mechanism have been handled by India in a remarkable fashion. Its robust institutions have regulated the economy more fruitfully than those which regulate democratic politics.

The above has helped in creation of a good social structure more successfully than creation of decent Work conditions for labour or a structure of redistributive transfers. Despite this its expert and watchful apparatus of developmental planning has tried to reduce the inequality in economic citizenship through numerous welfare oriented programmes covering the lower income people in many ways like by income, agro-ecological region, farm size, gender, life cycle, caste/ethnicity, skill level, nutritional status, etc.

But throughout the abovementioned process, though the planning mechanism has adhered to a universal norm of citizenship, in reality the bureaucracy has implemented practices of inclusion in such a fashion that the results unfortunately reinforce unequal economic citizenship. Despite this India has managed to deal with the above dichotomic reality and move forward on the path of Economic Citizenship, albeit slowly. 
In view of above analysis it would be reasonable to accept the fact that in the course of livelihood struggles, the disadvantaged social classes have fewer claims on state and society, in comparison with individuals belonging to dominant classes. This social reality is in sharp contrast to the Indian constitution's guarantee of equality before the law, as well as substantive economic equality to all its citizens.

As we have seen the concept of Economic Citizenship relies on the existence of a plurality of social classes, so that all classes have equal and substantive claims to public and social resources. A regime of equality of opportunity and equality in outcomes warrants robust policy to ensure substantive equality. Here Substantive equality denotes steps which neutralise indirect discrimination; recognising and addressing not only current circumstances but also the historical legacy (Harries-White, Prakash, Mishra, January 2013a and Manhas, June 2020b).

To effectively achieve the substantive equality, India would need to reform the legacy of unequal wealth pattern which has made market forces non-neutral between individuals who are unequally endowed. Owing to this the market forces react to the signals emanating from standard Demand and Supply law and not to the citizens' rights. They respond to the logic of profit and shareholder value and setting aside equity or inclusive justice affecting both the Citizens and Security.

As a remedy, market forces need to change in two ways:-

a) Through competition and technological changes

b) Through commodification (involving new commodities and commodified, services, the commodification of the public sphere, public space, the domestic sphere, for the common good.

India also needs to integrate its polity/civic society and prepare it for a formal role in the national and economic citizenship development. India needs to overcome the party politics and create an increased space for political pluralism (the expression of a diversity of interests), progressively translating it into an economic inclusion or social plurality. It also needs to reduce the social strife which constitutes a threat both to economic citizenship and security environment.

India needs to thus accelerate the process which it has already embarked upon for moving towards Economic Citizenship, which is following a trajectory different from the West in several respects, based on its own peculiarities like:- 
a) It is a member of international organisations regulating trade and commerce; it is the acknowledged leader of the developing world at the WTO, and it articulates the aspirations of developing countries in international negotiations on environment and energy.

b) Indian foreign direct investment has been characterised by a proliferation of mergers and acquisitions of elite businesses in Europe, Latin America, the United States, and Africa.

c) India supplies a crucial workforce to the Middle East.

d) India is economically powerful and politically influential through its highly skilled migrants in top OECD countries (the United States, Canada and Australia) and Seventy percent NRIs in the Gulf region with semi- or unskilled labour.

The above factors have their own dynamics and have caused emergence of some general patterns as outlined by Harris-White, Cuddy Keane, Manhas and in ABP News (Harries-White, Prakash, n.d) (Cuddy-Keane, September 2003b) (Manhas, June 2020c) (ABPNEWS, March 13, 2021):-

a) The economic forces unleashed by globalisation have generated parallel and contradictory processes. A very small proportion of Indian citizens are transnational let alone post-national. Their political strength results from their ability to use the Indian state to support their place in the market. While being post-national in the international arena they do not see reasons to challenge the practices of economic citizenship discussed earlier.

b) As has happened elsewhere in the world, in India too, the social authority of the nation over post-national citizens has been considerably weakened. Despite this, the Indian diaspora, or workers of Indian origin, appeal to the political power of the Indian state to counter their experience of economic marginalisation (as in the case of Malaysia), poor labour conditions (the Gulf), or cultural rejection (e.g. the recent turban case in Canada) on the foreign shores where they reside and work. However, India generally confines the weight of its support to elite migrants.

c) There is strong demand for dual citizenship from the NRI diaspora, nurtured by ties of kinship and remittances. For many there is a contradiction between cultural marginalisation in their place of residence (against which they campaign) and citizenship based on cultural exclusion within India itself. Dual citizenship has been 
granted to NRIs from only 16 countries, none of which are countries where Indian migrants are low-skilled wage labour.

d) India needs to deal with the constituent states where non-local Indian political citizens have barely any economic rights. These non-local Indian political citizens are not accepted by the states as they eat into the jobs of local population and are often shunned by the local authorities. It is not an easy problem to deal with.

e) Further India has to handle insistence of regional governments on reserving $75 \%$ jobs in various sectors for local people, as it is unlikely to help (due to disparity in required and available qualification/skills) either the regional or national cause.

Though conceptually India is marching forward on the road to Economic citizenship, effective consensus is still eluding it. As a result, the Economic Citizenship has a long way to go in India. It is, therefore, important for India to understand the economic dynamics and pursue policies of socio-economic inclusion of it citizens and gradually move towards Economic Citizenship.

It is acknowledged that Economic Citizenship has its own disadvantages, as pointed out by Harris-White and Prakash (Harris-White \& Prakash, n.d):-

a) The time it takes to complete the process could be long.

b) The level of investment required may vary without a perceptible logic.

c) Government may change the policies, criteria or requirements at any time, without much notice.

d) Citizenship-by-investment programs may suffer from lack of transparency and accountability

Despite the above disadvantages, the Economic Citizenship seems to be a better way forward for India.

\section{Conclusion and Recommendations}

Globalisation has become an inescapable necessity today and it is here to stay. The world has already started adapting to the Globalisation, EU stands as a good example.

Indian too needs to accept that Globalisation is an irreversible process now. It has certainly affected many aspects in India including Citizenship. India needs to do some out of the box 
thinking to reap the benefits of Globalisation and rationalise its Citizenship process. Adaption of Economic Citizenship could be a way forward. Some suggested measures are:-

a) The States, markets, and civil society should effectively deal with challenges from its emigrant capital (visible and invisible) and from immigrant capital, from trans- and post-national e'migre' professional classes and emigrant working people along with the demands of incoming global business, communications, politics, and civil society.

b) Some of these incoming forces come with hallmarks of economic citizenship nurtured in the very different conditions of OECD countries. Thus India's states, markets and civil society must remove the age old class and status barriers and also deal with the painful anti-developmental processes.

c) Effectively deal with security issues emerging from migrants from various countries, balancing both the security and economic environment.

d) Commission a detailed study to analyse the current trends in Globalisation, impacts on various aspects including Citizenship and come up with implementable forward looking policies.

Finally, some of the issues which have not been dealt in detail here but would need to be focused on separately are:-

a) Impact of enhanced exodus of people from Myanmar into India.

b) Difficulties in identifying the migrants from neighbouring countries due to ethnic similarity and impact on society.

c) Impact of foreign support to disruptive forces e.g. support to insurgencies, clandestine migration etc.

d) Domestic and global criticism of NRC and CAA.

\section{Acknowledgement:}

Author would like to acknowledge the valuable suggestions from Dr R Srinivasan in writing this article. 


\section{References:}

1. ABP New Bureau,( Mar 13, 2021), Jharkhand Follows Haryana's Footsteps As Cabinet Approves Policy Of 75\% Pvt Job Reservation For Locals, abp LIVE, Online, Retrieved from:

https://news.abplive.com/news/india/after-haryana-jharkhand-government-clears-75private-sector-reservation-1448279, Accessed on 25 Mar 2021

2. Achiron Maryline (Nov, 2005), Nationality and Statelessness, UNHRC-UNRA (https://www.refworld.org/pdfid/53d0a0974.pdf), Retrieved from: https://www.un.org/ruleoflaw/files/Nationality\%20and\%20Statelessness.pdf , Accessed on 21-22 Feb 2021

3. Anand Utkarsh (Mar 26, 2021), India can't become capital of illegal migrants: Govt on Rohingyas' deportation plea Hindustan Time, Online, Retrieved from: https://www.hindustantimes.com/india-news/india-can-t-become-capital-of-illegalmigrants-govt-on-rohingyas-deportation-101616754569448.html, Accessed on 27 Mar 2021

4. Britannica Encyclopaedia (2020), Citizenship, Britannica Encyclopaedia, Online, Retrieved from- https://www.britannica.com/topic/citizenship, Accessed on 21 and 28 Feb 2021

5. Cuddy-Keane M, ( Sep, 2003), Modernism, Geopolitics, Globalization, Modernism/modernity, https://muse.jhu.edu/article/46433, The Johns Hopkins University Press Volume 10, Number 3, September 2003, pp. 539-558 (Article),DOI 10.1353/mod.2003.0057, Online, Retrieved from: https://www.researchgate.net/publication/236772398_Modernism_Geopolitics_Globa lization, Accessed on 21-22-24 Mar 2021

6. Czaika, Mathias \& de Haas, Hein (2014), The Globalization of Migration: Has the World Become More Migratory? International Migration Review. 48.

10.1111/imre.12095, Online, Retrieved from: https://www.researchgate.net/publication/262492737_The_Globalization_of_Migratio n_Has_the_World_Become_More_Migratory, Accessed on 23-24 Feb 2021

7. Elliott A, \& Turner BS (2012), Book (Print Form), Polity, On Society, ISBN-13: 9780-7456-4842-2 (Preface and Pages 9 and 15 to 19). Referred Feb 2021.

8. ECPR (July 2016). Globalisation, Citizenship and Migration, EPCR Graduate Students' Conference, University of Tartu, 13-16 Jul 2016, Section Number. S 11: Abstract, Online, Retrieved from: https://ecpr.eu/Events/Event/SectionDetails/496. Accessed on 22-23 Feb 2021. 
9. Ghaderi Timoreh ( September 20, 2015), Globalisation Concept Map, Prezi, Online, Retrieved from: https://prezi.com/ibonwmfv3lyy/globalization-concept-map/ , Accessed on 23 Mar 2021

10. Handler Joel F, (September, 2002), Social Citizenship and Workfare in the United States and Western Europe: From Status to Contract, Basic Income European Network (BIEN), Vancouver, Canada, Retrieved from: http://www.ilo.org/public/english/protection/ses/download/docs/handler.pdf, Accessed on: 22-23 Mar 2021

11. Harris-White B, Prakash Aseem, Mishra Deepak ( Jan 2013), Researchgate, Globalisation, Economic Citizenship, and India's Inclusive Developmentalism (DOI: 10.1007/978-3-642-34568-5), Chapter 10, In book: Citizenship as Cultural Flow: Structure, Agency and Power (pp.187-210), Springer (ISBN 978-3-642-345685), Online, Retrieved from: https://www.researchgate.net/publication/267789011_Globalisation_Economic_Citize nship_and_India's_Inclusive_Developmentalism, Accessed on 21-22 Mar 2021

12. Harris-White B, Prakash Aseem, (n.d), Oxford University, Social Discrimination In India: A Case For Economic Citizenship, Retrieved from: https://southasia.web.ox.ac.uk/sites/default/files/southasia/documents/media/oxford_u niversity_csasp_work_in_progress_paper_5_social_discrimination_in_india_a_case _for_economic_citizenship.pdf, Accessed on 23-23-25 Mar 2021

13. Huwart, Jean-Yves and Loïc Verdier (2013), "What is the impact of globalisation on the environment?", in Economic Globalisation: Origins and consequences, OECD Publishing, Paris. DOI: https://doi.org/10.1787/9789264111905-8-en , Retrieved From : https://www.oecd-ilibrary.org/docserver/9789264111905-8en.pdf?expires $=1621669983 \& \mathrm{id}=\mathrm{id} \&$ accname $=$ guest $\&$ checksum $=1 \mathrm{ECD} 95 \mathrm{~F} 4 \mathrm{BE} 656$ D74729E87EC73C2C882, Accessed on 22 May 2021

14. Kabeer Naila, (Dec 27, 2005), Inclusive Citizenship: Meanings and expressions, Book-ISBN1 84277549 9, Zed Books, Accessed in Book Format, Accessed Feb 2021

15. Kivisto Peter and Faist Thomas, (2007), Citizenship: Discourse, Theory, and Transnational Prospects (page 102), Wiley-Blackwell, ISBN: 978-1-405-10551-4, Book, Referred Jan- Feb 2021

16. Kosar Khalid (March 2018), International Migration: A Canary in the Coalmine of Globalisation, Graduate Institute Geneva, Global Challenges, Issue no.3, Article 4 (online). Retrieved From: https://globalchallenges.ch/issue/3/international-migrationa-canary-in-the-coalmine-of-globalisation/, accessed on 23-24-28 Feb 2021. 
17. Kymlicka W and Norman W, (1994), Return of the Citizen: A Survey of Recent Work on Citizenship Theory, Ethics, Vol 104, No 2, pp 352-81, University of Chicago Press, Book, Referred Feb 2021

18. Manhas Neeraj Singh, ( Jun 2020), Globalization and Its Impact on Indian Economy (DOI: 10.25215/2455/0502015), International Journal of Social Impact ISSN: 2455-670X Volume 5, Issue 2, DIP: 18.02.015/20200502/www.ijsi.in |April June, 2020, Retrieved from:

https://www.researchgate.net/publication/344045305_Globalization_and_Its_Impact_ on_Indian_Economy, Accessed on 23-24 Feb 2021

19. Marshal TH (1950), CITIZENSHIP AND SOCIAL CLASS and other essays, Cambridge University Press, Accessed Online and Retrieved From: http://www.jura.unibielefeld.de/lehrstuehle/davy/wustldata/1950_Marshall_Citzenshi p_and_Social_Class_OCR.pdf, Accessed on 22 May 2021

20. Mohanty Prasanna (Dec 24, 2019), CAA \& NRC: The two together pose a serious threat to India's development story, Business Today, Online, Retrieved from: https://www.businesstoday.in/current/economy-politics/caa-and-nrc-these-two-posea-serious-threat-to-indias-development-story-muslims-religious-fundamentalismsecular-amit-shah/story/392319.html, accessed on 23-24 Mar 2021

21. Montiglio Daniel (n.d), 14 Reasons Why People Immigrate, Foreigner.BG, Online, Retrieved From: https://www.foreigner.bg/12-reasons-why-people-immigrate/, accessed on 23-24 Feb 2021

22. Navarro Joaquine V, (Apr, 2005), Social Citizenship and the Environment, Environmental Politics, Vol. 14, No. 2, 239 - 254( DOI: 10.1080/09644010500055142), Online, Retrieved from: https://www.researchgate.net/publication/313024890_Social_Citizenship_and_the_En vironment, Accessed on 23-24 Mar 2021

23. Nuñez Chistina, Sánchez Erica and Sepehr Jana, (Dec 04, 2014), Why people migrate: 11 surprising reasons, Global Citizen, On line, Retrieved from: https://www.globalcitizen.org/en/content/why-people-migrate-11-surprising-reasons/. Accessed on 23-24 Feb 2021

24. Radhakrishnan Sruthi (Jul 30, 2018), The Hindu explains: Citizenship by investment, The Hindu, On line, Retrieved from: https://www.thehindu.com/news/international/the-hindu-explains-citizenship-byinvestment/article24554040.ece, Accessed on 26-27 Feb 2021

25. Raj, Prachi (June 06, 2020). Understanding Citizenship and Refugees' Status in India, Economic and Political Weekly, Volume 55, Issue 23 (online). Retrieved From: 
https://www.epw.in/journal/2020/23/perspectives/understanding-citizenship-andrefugees-status.html Accessed on 22-23 Feb 2021

26. Roy Niranjan and Debnath Avijit (2011), Impact of Migration on Economic Development: A Study of some selected State ( 2011 International Conference on Social Science and Humanity), IPEDR vol.5 (2011) (C) (2011), IACSIT Press, Singapore, Retrieved from: http://www.ipedr.com/vol5/no1/42-H00092.pdf, Accessed on 26-27 Feb 2021

27. Soysal N Y, (1994), University of Chicago Press, Limits of Citizenship: Migrants and Post-national Membership in Europe, Book, Referred: Feb 2018

28. Turner Bryan ( Oct 10. 2017), Contemporary Citizenship-Four Types, Journal of Citizenship and Globalisation Studies, 2017; 1(1): 10-23, DE GRUYTER Open (https://doi.org/10.1515/jcgs-2017-0002 ), On Line, Retrieved From: https://www.researchgate.net/publication/320352628_Contemporary_Citizenship_Fou r_Types/link/59df72570f7e9b2dba832164/download , Accessed on 21-22 Feb 2021

29. UNHRC-1954 Convention Relating to the Status of Stateless Persons (English PDF), Retrieved from: https://www.unhcr.org/ibelong/wp-content/uploads/1954Convention-relating-to-the-Status-of-Stateless-Persons_ENG.pdf, (Committee Report), Accessed on 21 and 28 Feb 2021

30. Vuskane Linda (2011), The Impact of Globalisation on Citizenship, ), GRIN Verlag Munich (ISBN9783346098764), Retrieved from: https://www.grin.com/document/512307, Accessed on : 22-23 Mar 2021

31. WHO (ND), Definition of Globalisation, Retrieved from: https://www.who.int/topics/globalization/en/ Accessed on 23 and 28 Feb 2021

32. Youmatter, (Oct 06, 2020), Globalization: Definition, Benefits, Effects, Examples What is Globalization? youmatter.world, On Line, Retrieved from: https://youmatter.world/en/definition/definitions-globalization-definition-benefitseffects-examples/ accessed on 21-22-28 Feb 2021

\section{Additional Support References:}

33. Citizenship (2014), Edited By Richard Bellamy, Madeleine Kennedy-Macfoy, ISBN 9780415664868

34. Handbook for Parliamentarians (2005) UNHRC -UNRA (https://www.ipu.org/resources/publications/handbooks/2016-07/handbookparliamentarians-refugee-protection-guide-international-refugee-law) 
35. Purkey, A L (2013): “A Dignified Approach: Legal Empowerment and Justice for Human Rights Violations in Protracted Refugee Situations," Journal of Refugee Studies, Vol 27, No 2.

36. Roy Anupama (2010): Mapping Citizenship in India, New Delhi: Oxford University Press ISBN: 9780198066743

37. Smith Peter J, (2002), The Impact of Globalization on Citizenship: Decline or Renaissance? Journal of Canadian studies. Revue d'études canadiennes 36(1):116140.

38. UN Report on Refuges and Migrants, 2017, UNHRC, People without nationality face 'stark realities' of discrimination and persecution - UN report No 03 , Retrieved from: https://refugeesmigrants.un.org/people-without-nationality-face$\%$ E2\%80\%98stark-realities\%E2\%80\%99-discrimination-and-persecution$\%$ E2\%80\%93-un-repv 2017 , accessed on 21 Feb 2021 